\title{
Average Altitude of the Water Table (1990-99) and Frequency Analysis of Water Levels (1974-99) in the Biscayne Aquifer, Miami-Dade County, Florida
}

By A.C. Lietz, Joann Dixon, and Michael Byrne

U.S. GEOLOGICAL SURVEY

Open-File Report 02-91

Prepared in cooperation with the

MIAMI-DADE DEPARTMENT OF ENVIRONMENTAL RESOURCES MANAGEMENT

U.S. DEPARTMENT OF THE INTERIOR U.S. GEOLOGICAL SURVEY
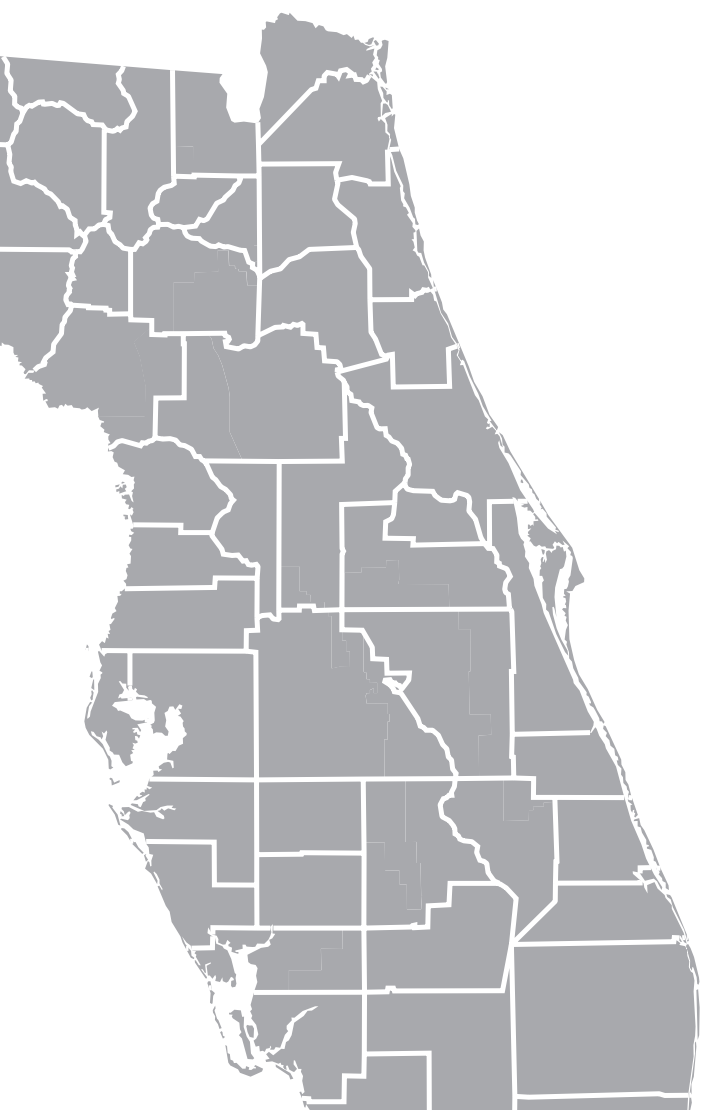

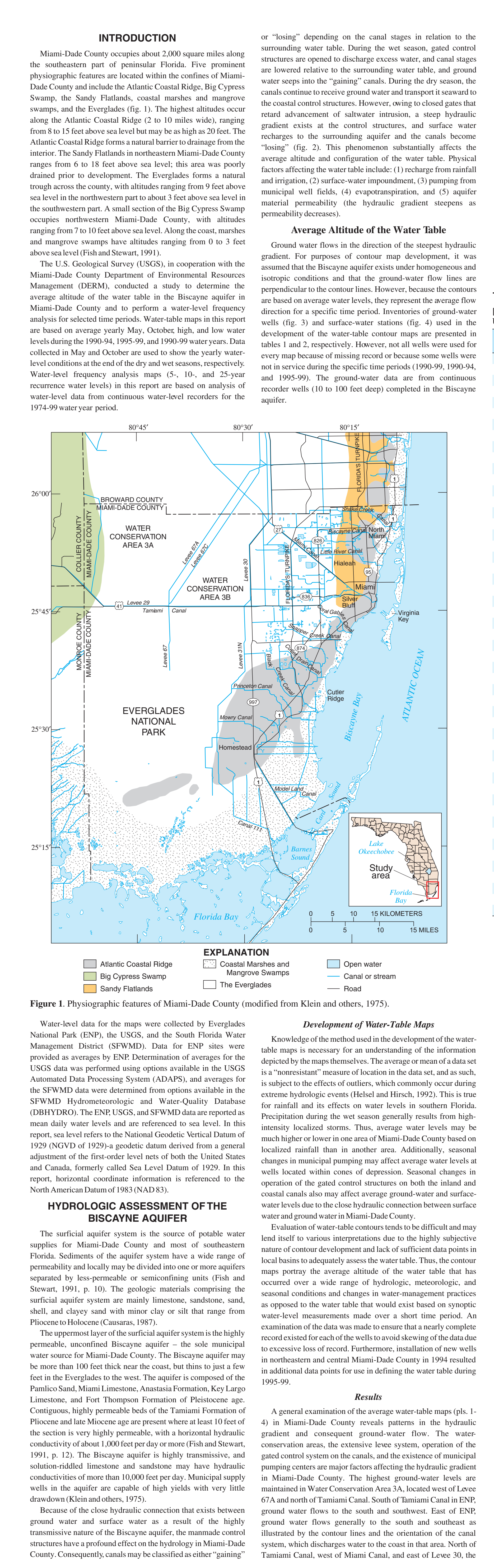
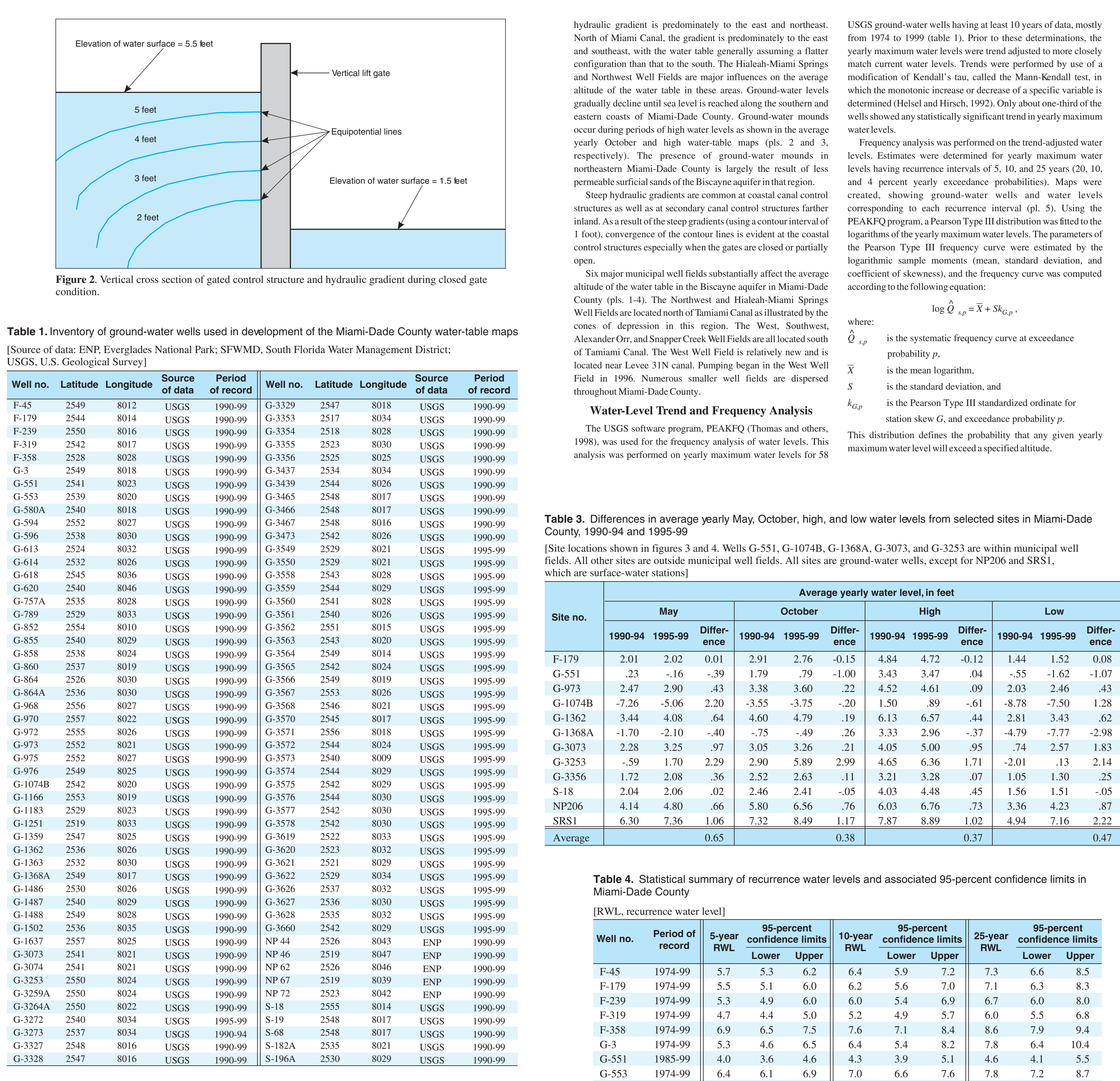

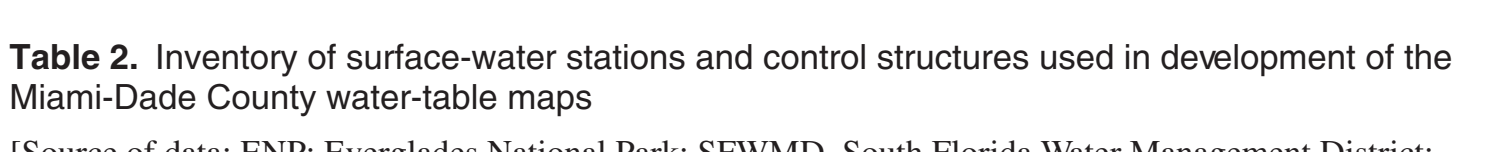

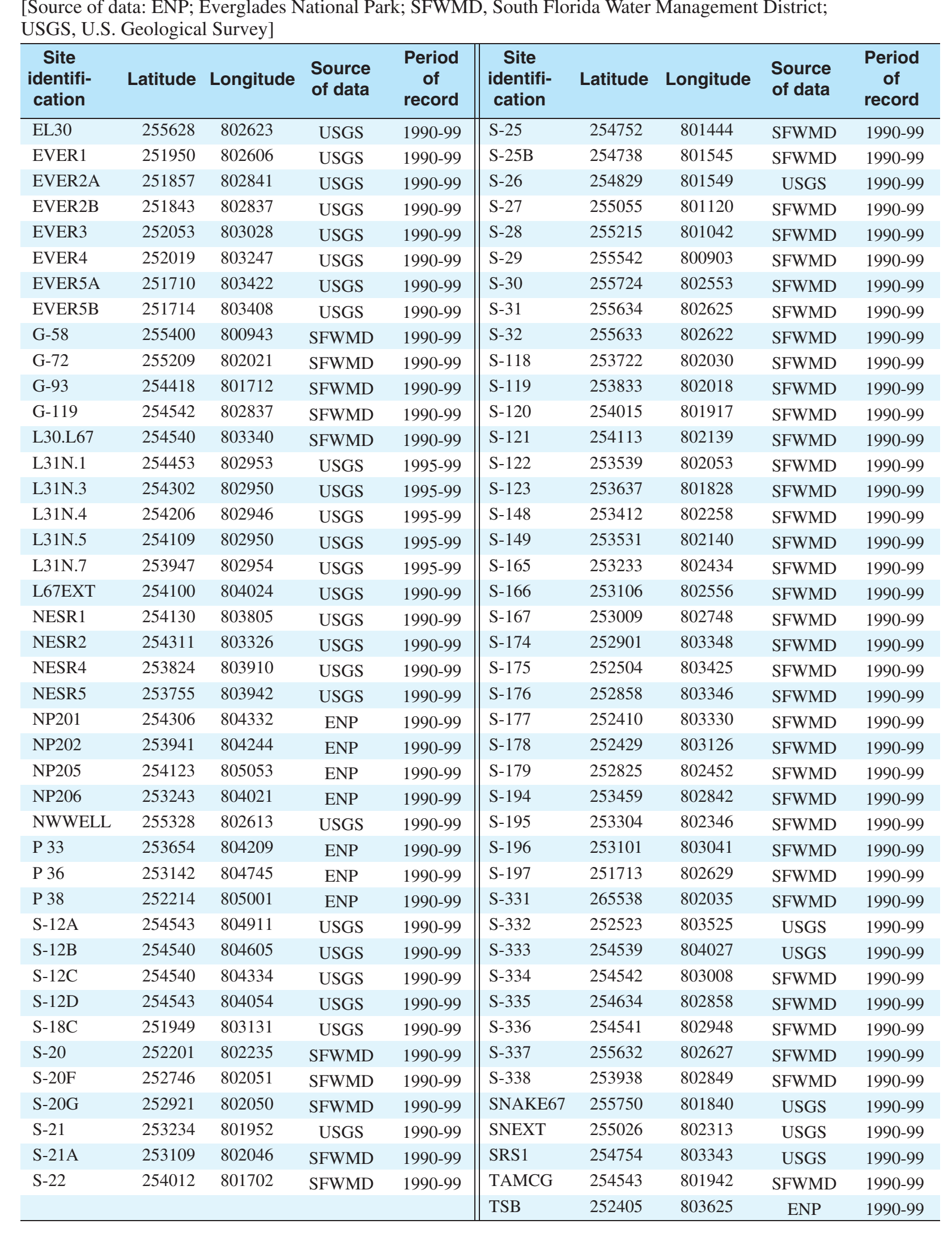

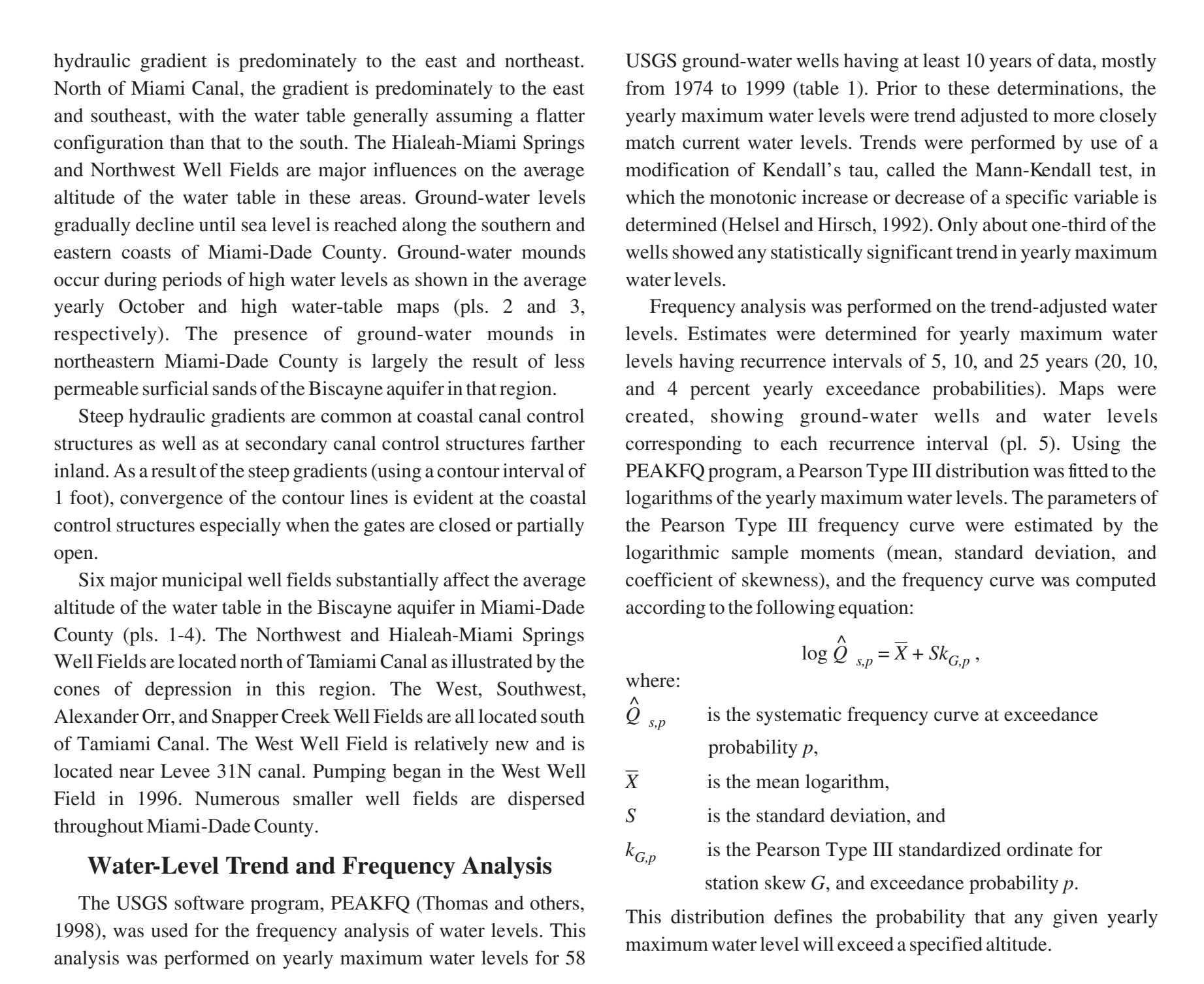
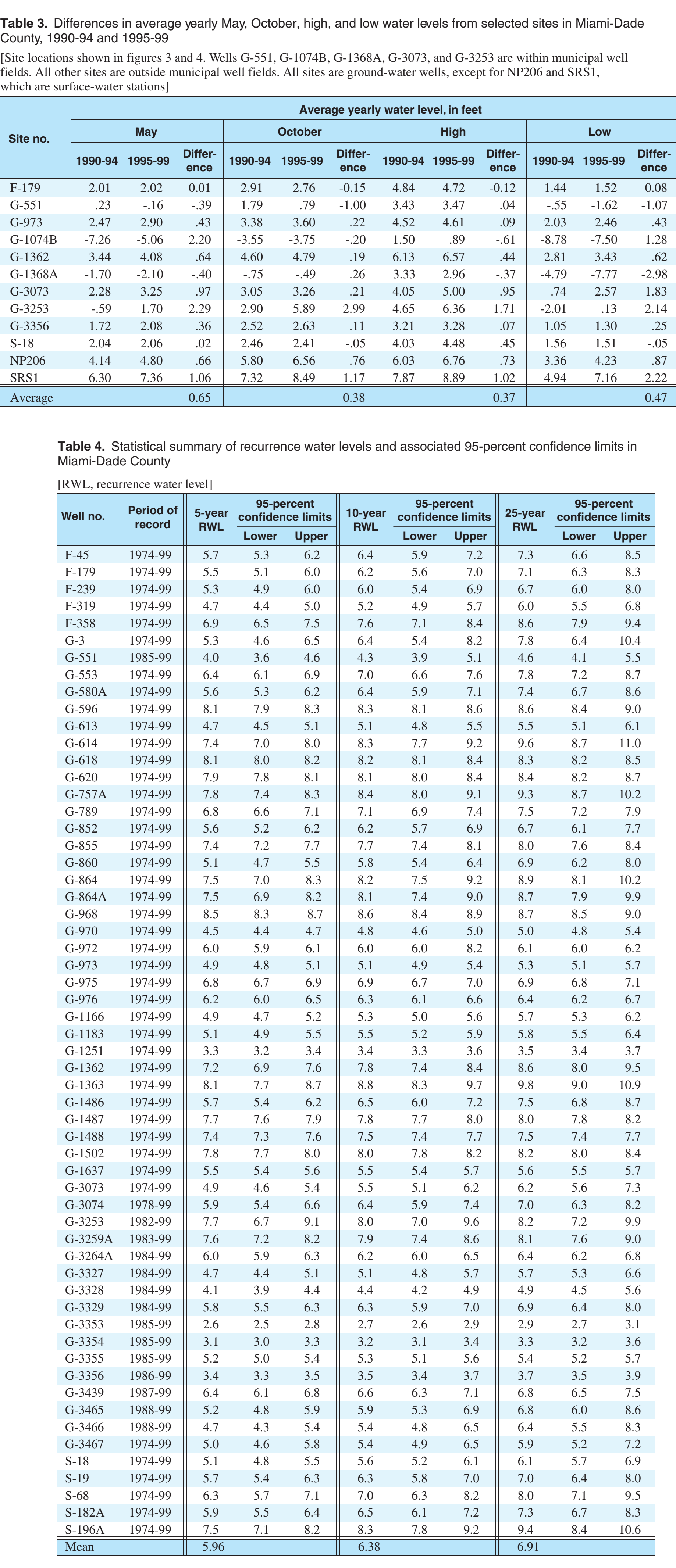
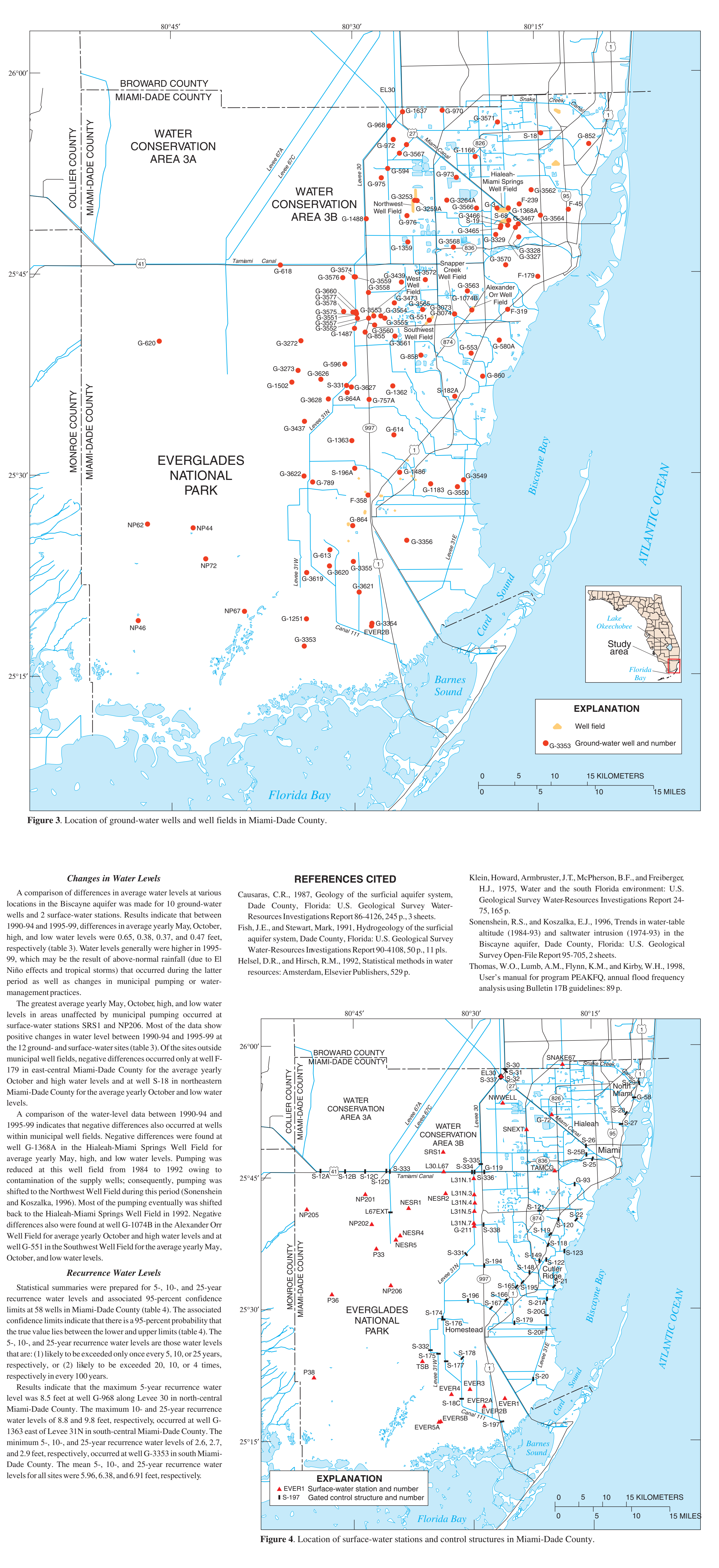

AVERAGE ALTITUDE OF THE WATER TABLE (1990-99) AND FREQUENCY ANALYSIS OF WATER LEVELS (1974-99) IN THE BISCAYNE AQUIFER, MIAMI-DADE COUNTY, FLORIDA 

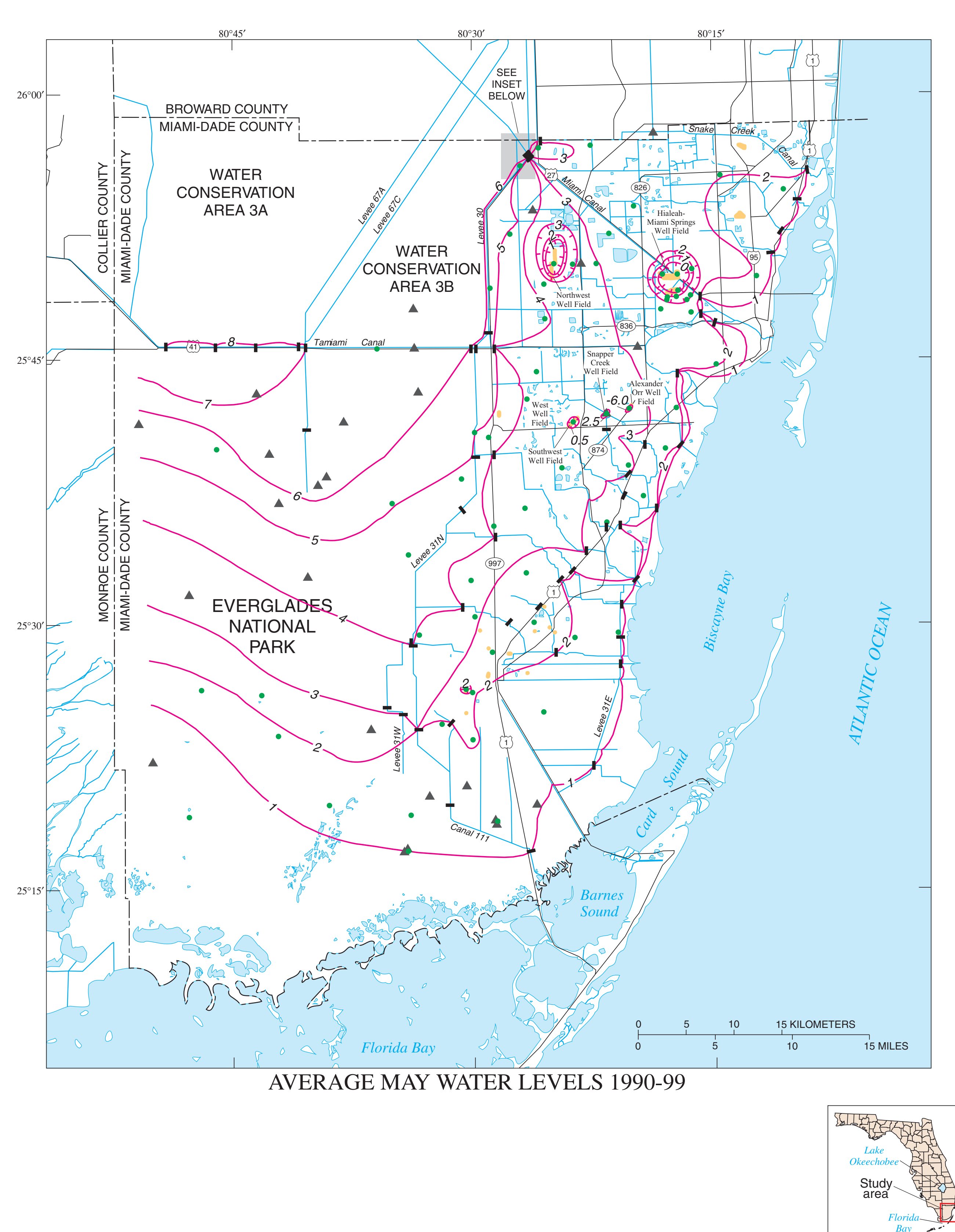

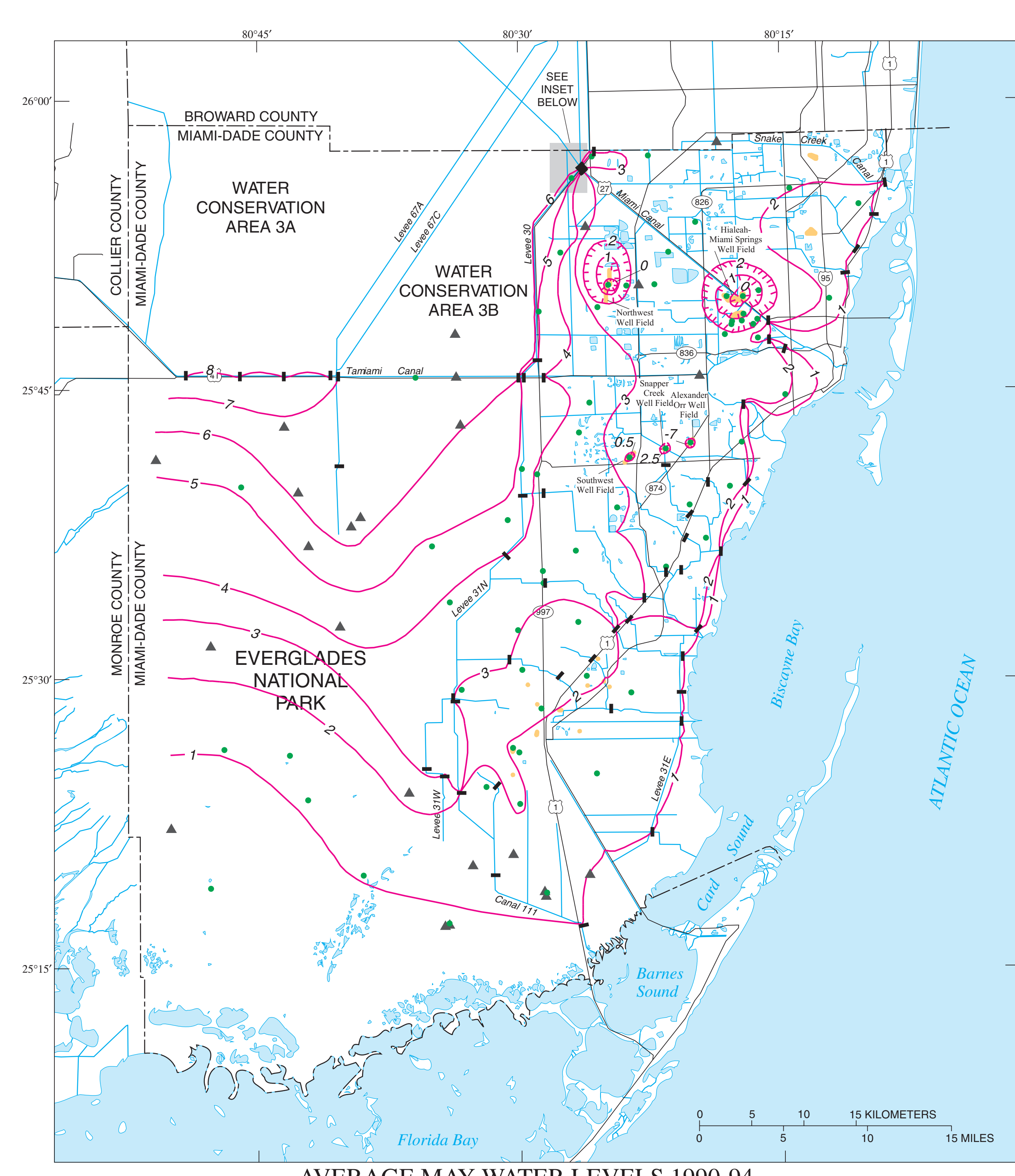

EXPLANATION

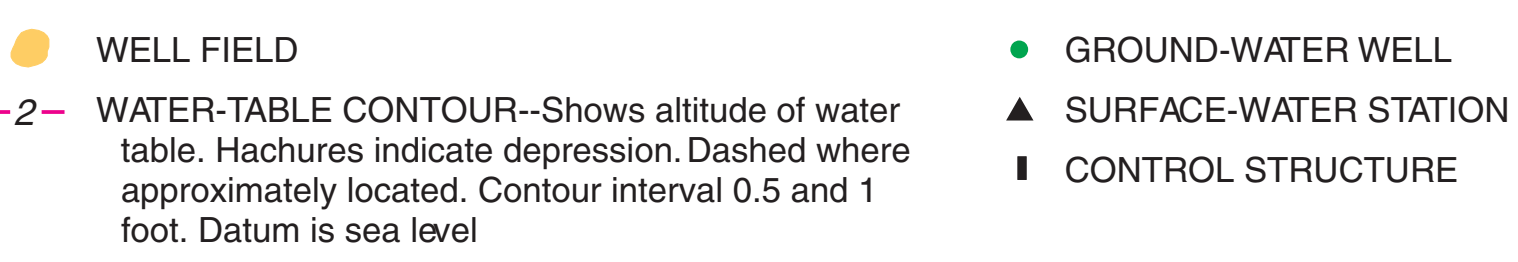

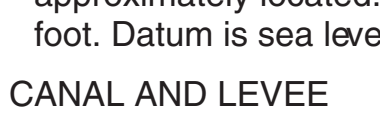
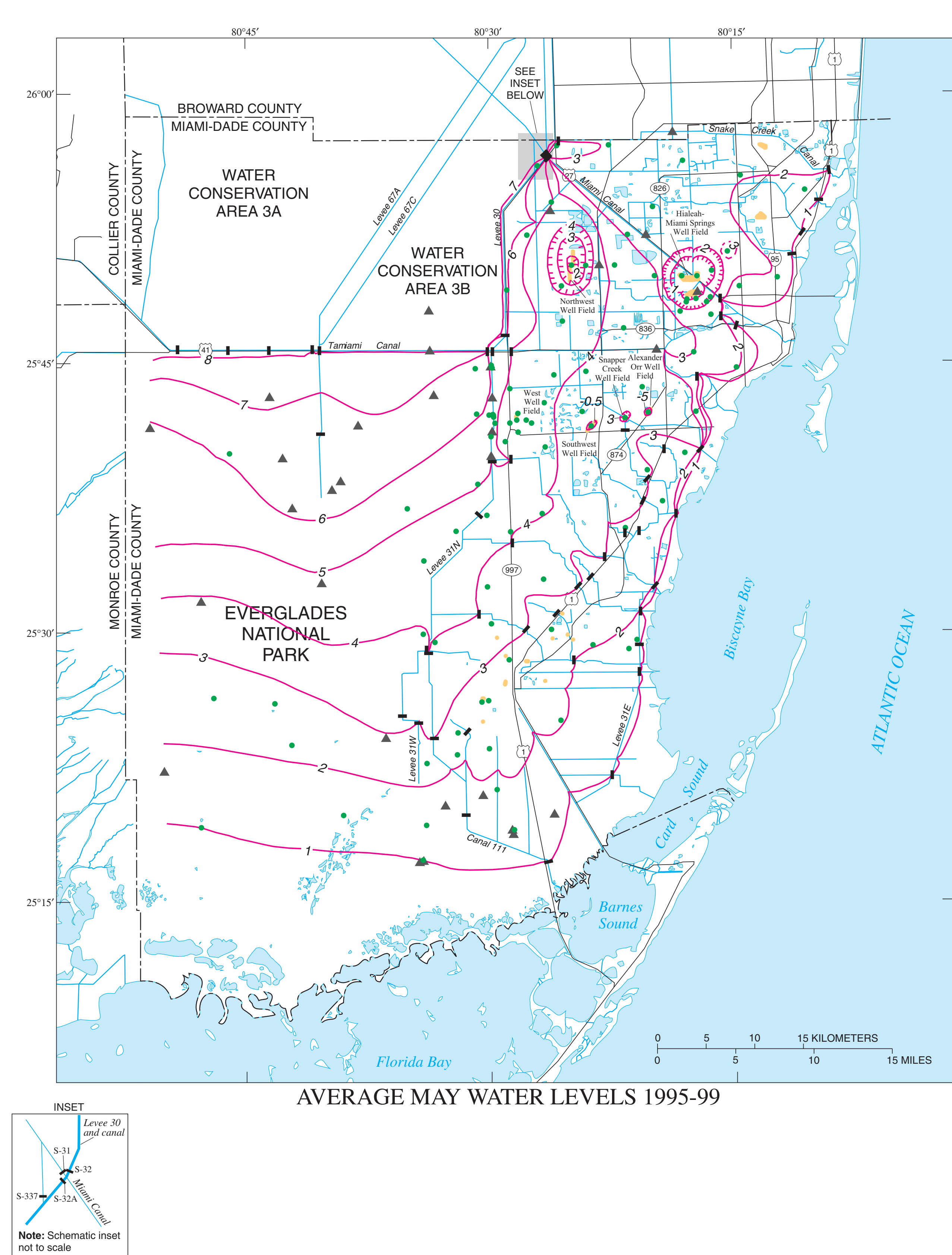

PLATE 1. MAPS SHOWING ALTITUDE OF THE WATER TABLE IN THE BISCAYNE AQUIFER, MIAMI-DADE COUNTY, FLORIDA, BASED ON AVERAGE YEARLY MAY WATER LEVELS FOR 1990-99, 1990-94, AND 1995-99

$$
\begin{gathered}
\text { By } \\
\text { A.C. Lietz, Joann Dixon, and Michael Byrne } \\
2002
\end{gathered}
$$




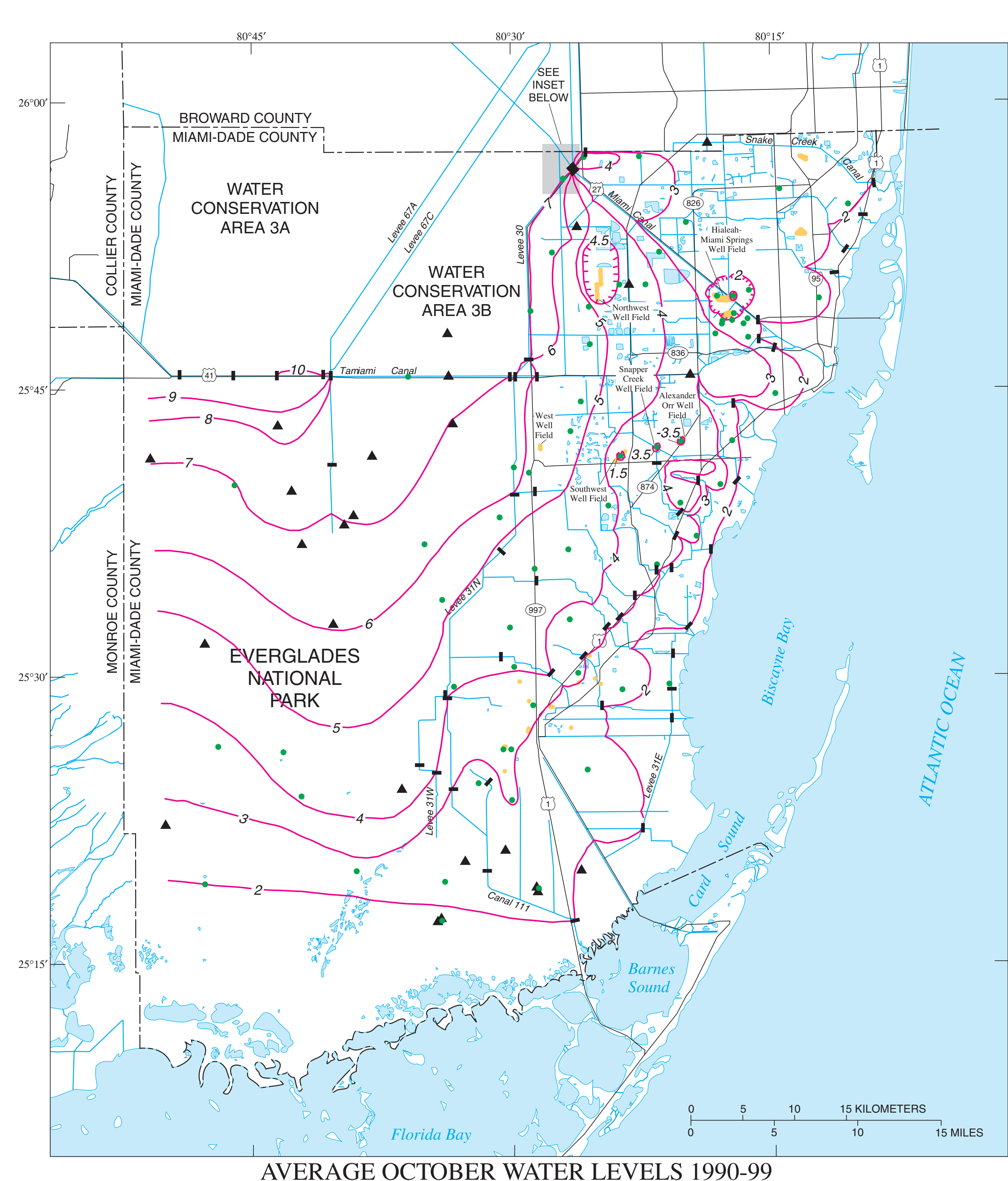

AVERAGE OCTOBER WATER LEVELS 1990-99

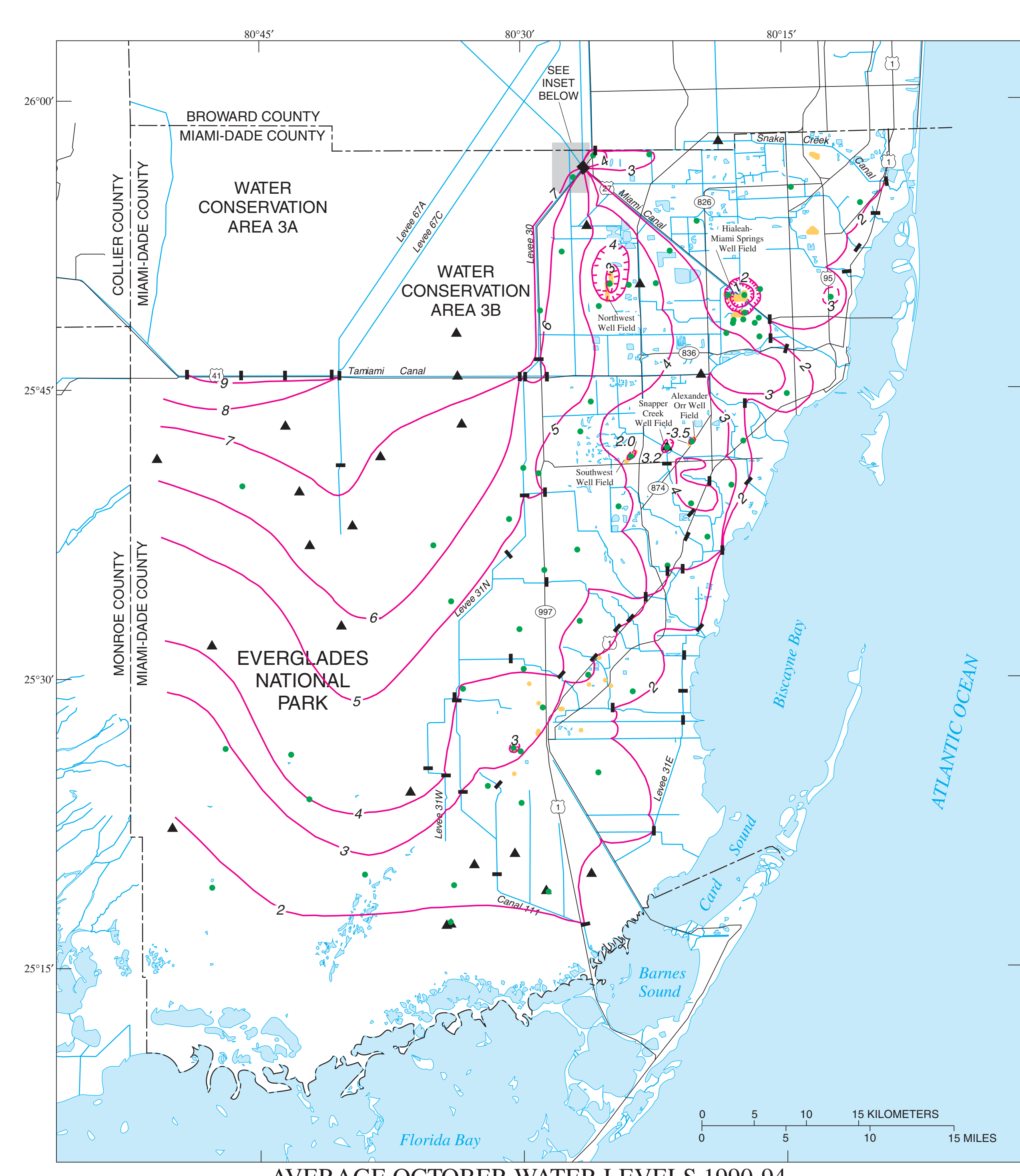

EXPLANATION

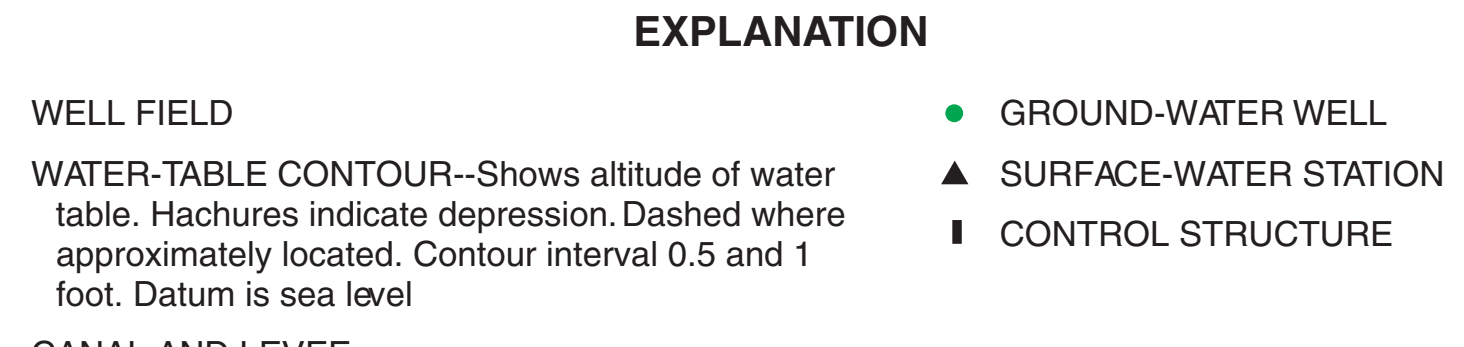

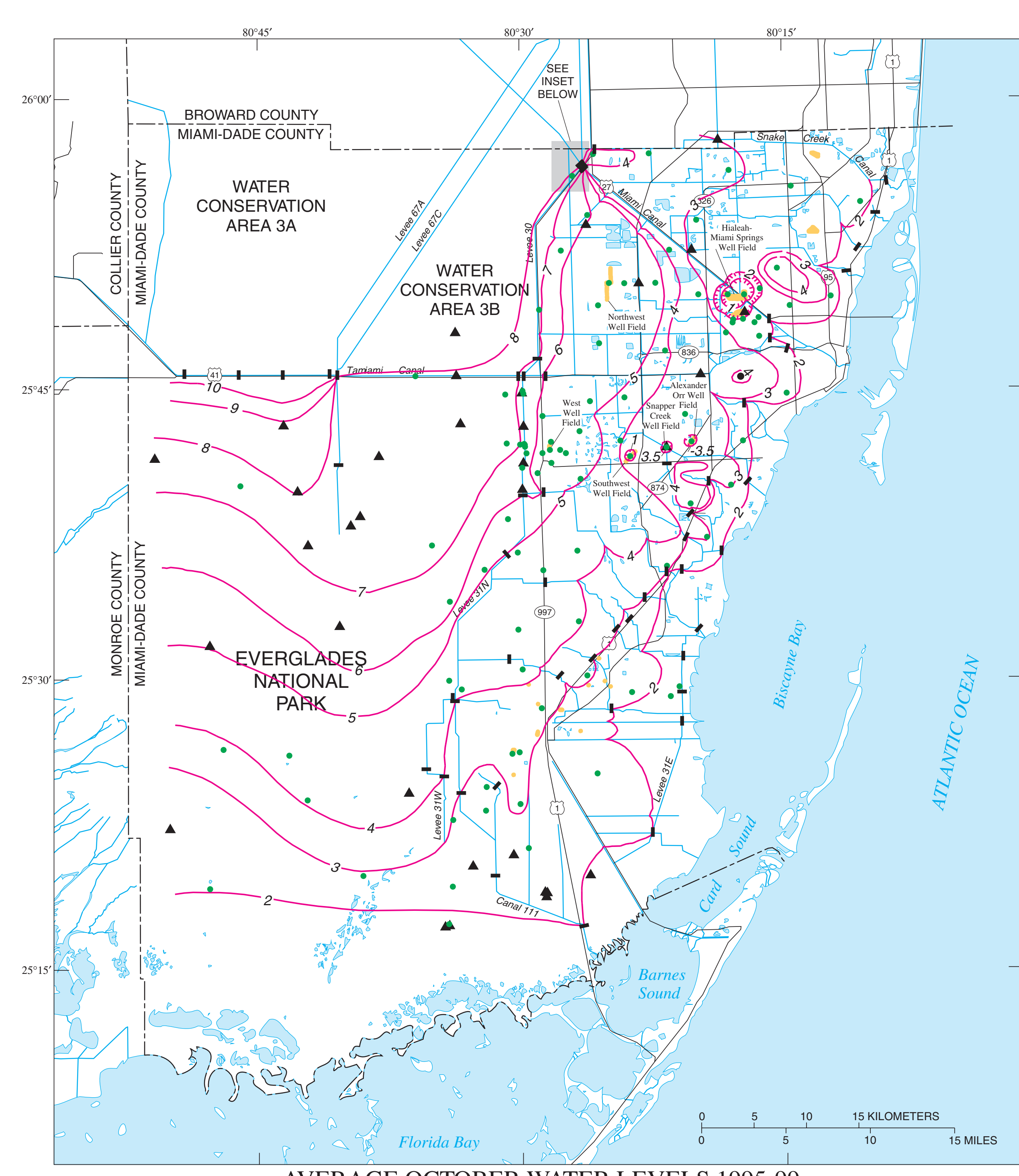

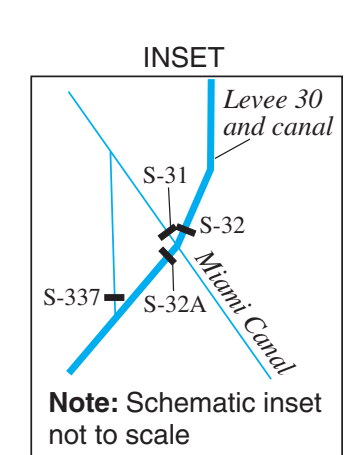

PLATE 2. MAPS SHOWING ALTITUDE OF THE WATER TABLE IN THE BISCAYNE AQUIFER, MIAMI-DADE COUNTY, FLORIDA, BASED ON AVERAGE YEARLY OCTOBER WATER LEVELS FOR 1990-99, 1990-94, AND 1995-99

$$
\begin{gathered}
\text { By } \\
\text { A.C. Lietz, Joann Dixon, and Michael Byrne } \\
20022
\end{gathered}
$$




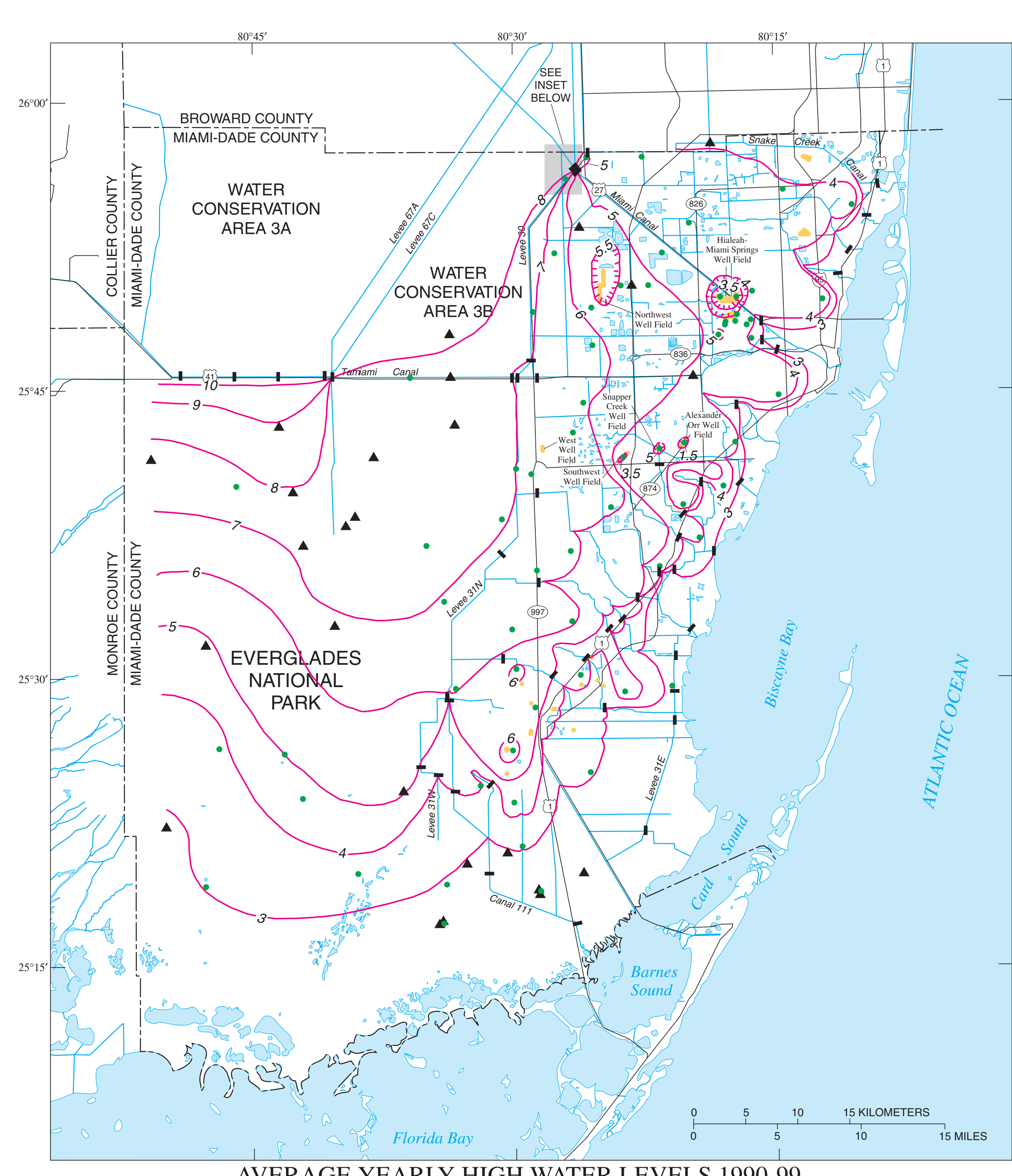

AVERAGE YEARIY HIGH WATER LEVELS 1990-99



EXPLANATION

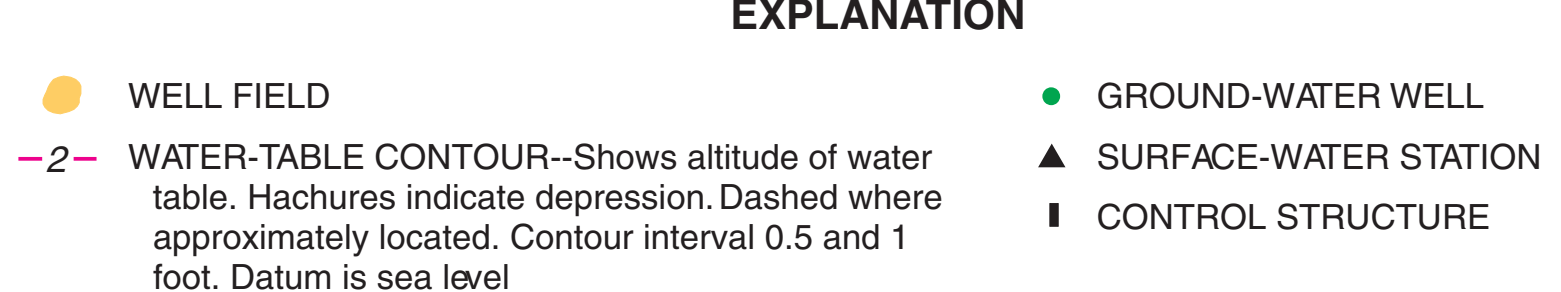

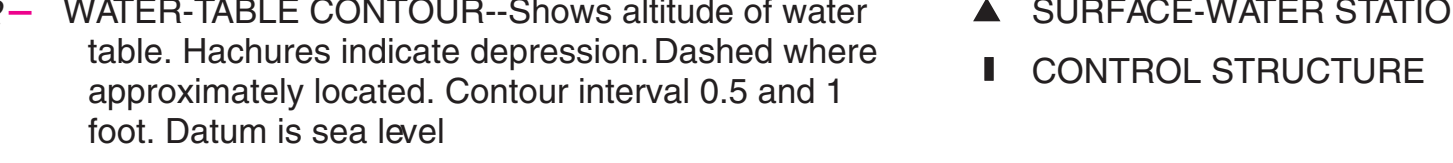

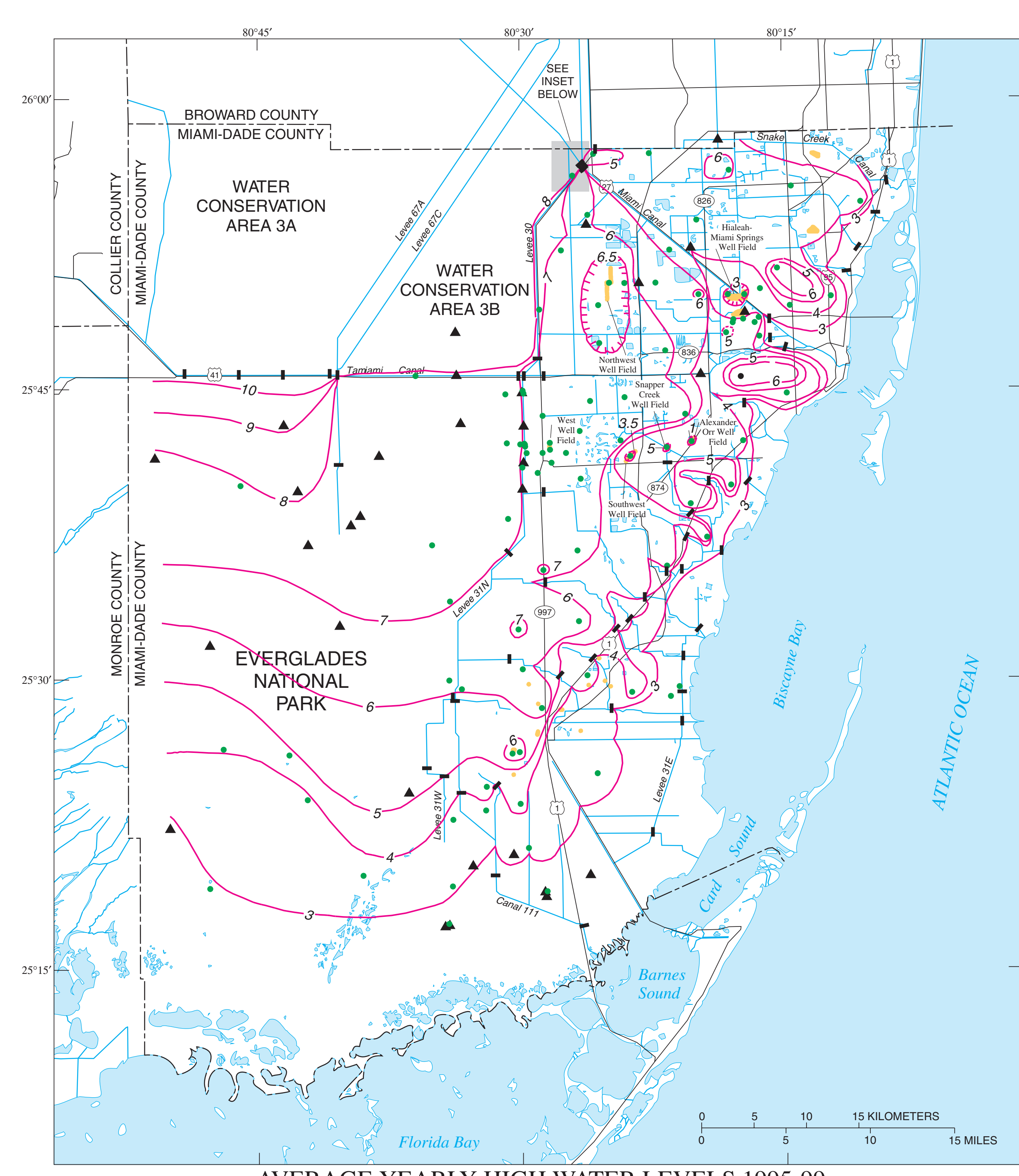

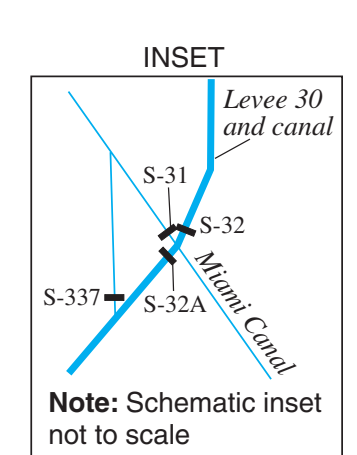

PLATE 3. MAPS SHOWING ALTITUDE OF THE WATER TABLE IN THE BISCAYNE AQUIFER, MIAMI-DADE COUNTY, FLORIDA, BASED ON AVERAGE YEARLY HIGH WATER LEVELS FOR 1990-99, 1990-94, AND 1995-99

$$
\begin{gathered}
\text { By } \\
\text { A.C. Lietz, Joann Dixon, and Michael Byrne } \\
2002
\end{gathered}
$$




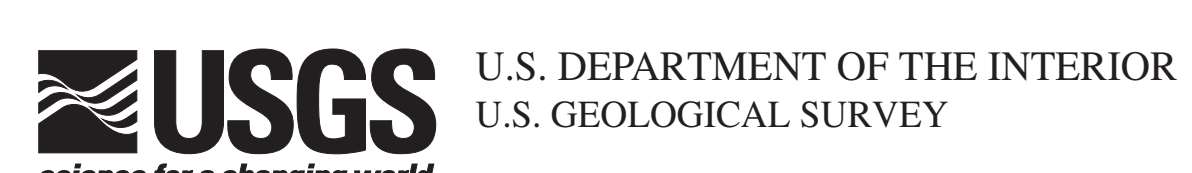

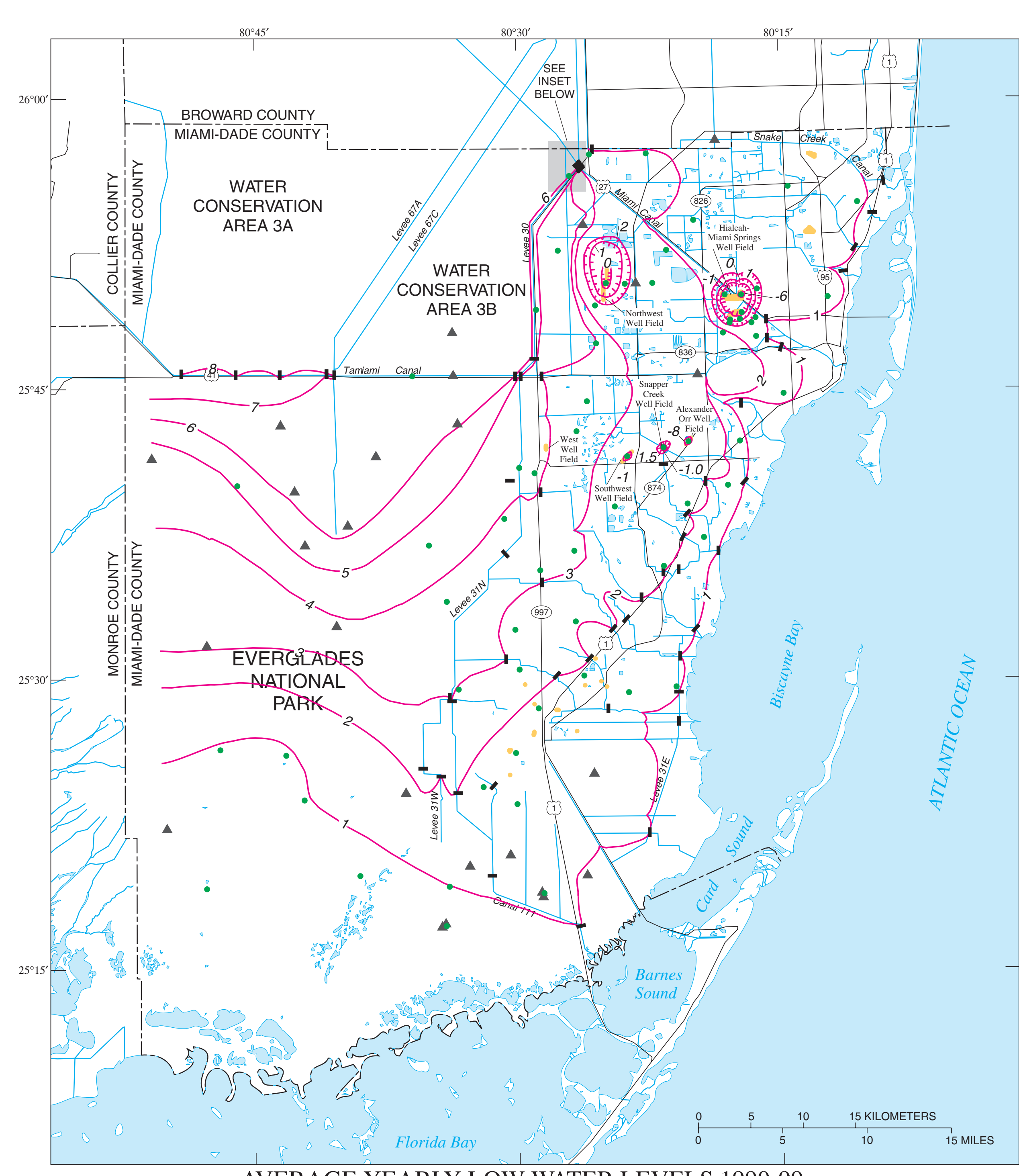

AVERAGE YEARLY LOW WATER LEVELS 1990-99

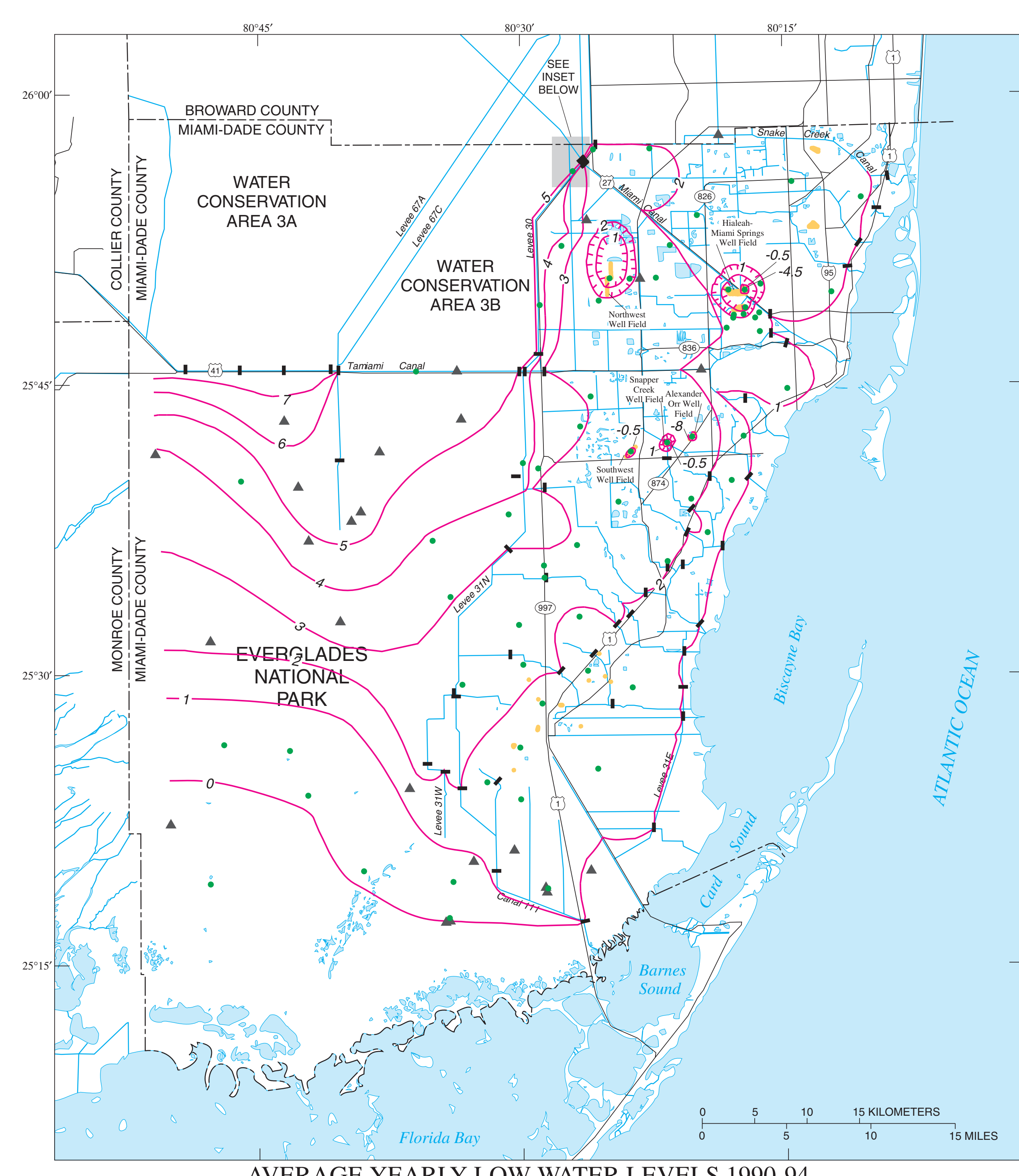

AVEAGE YEARIY LOW WATER LEVELS 1990-94 EXPLANATION

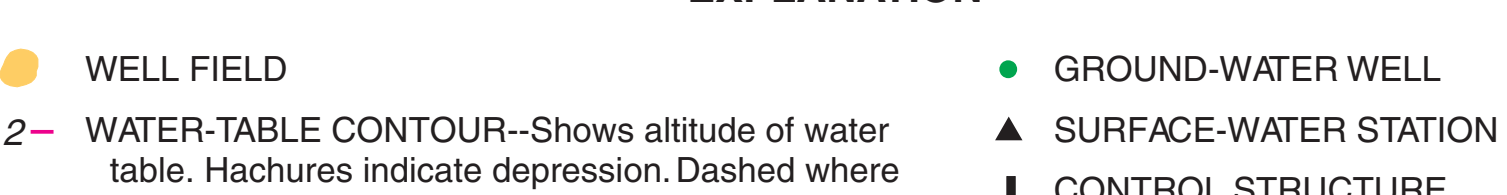

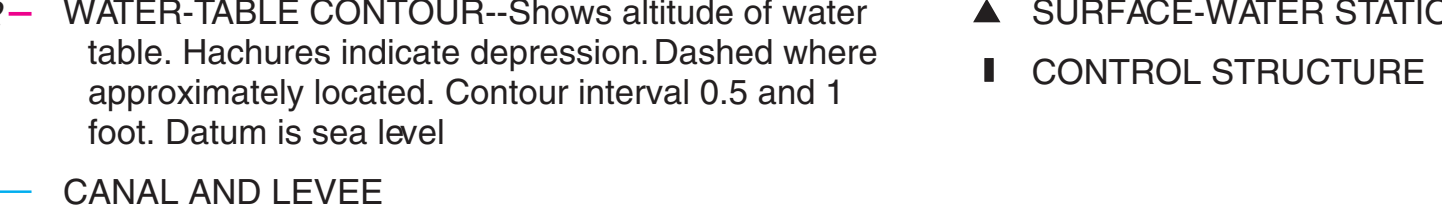

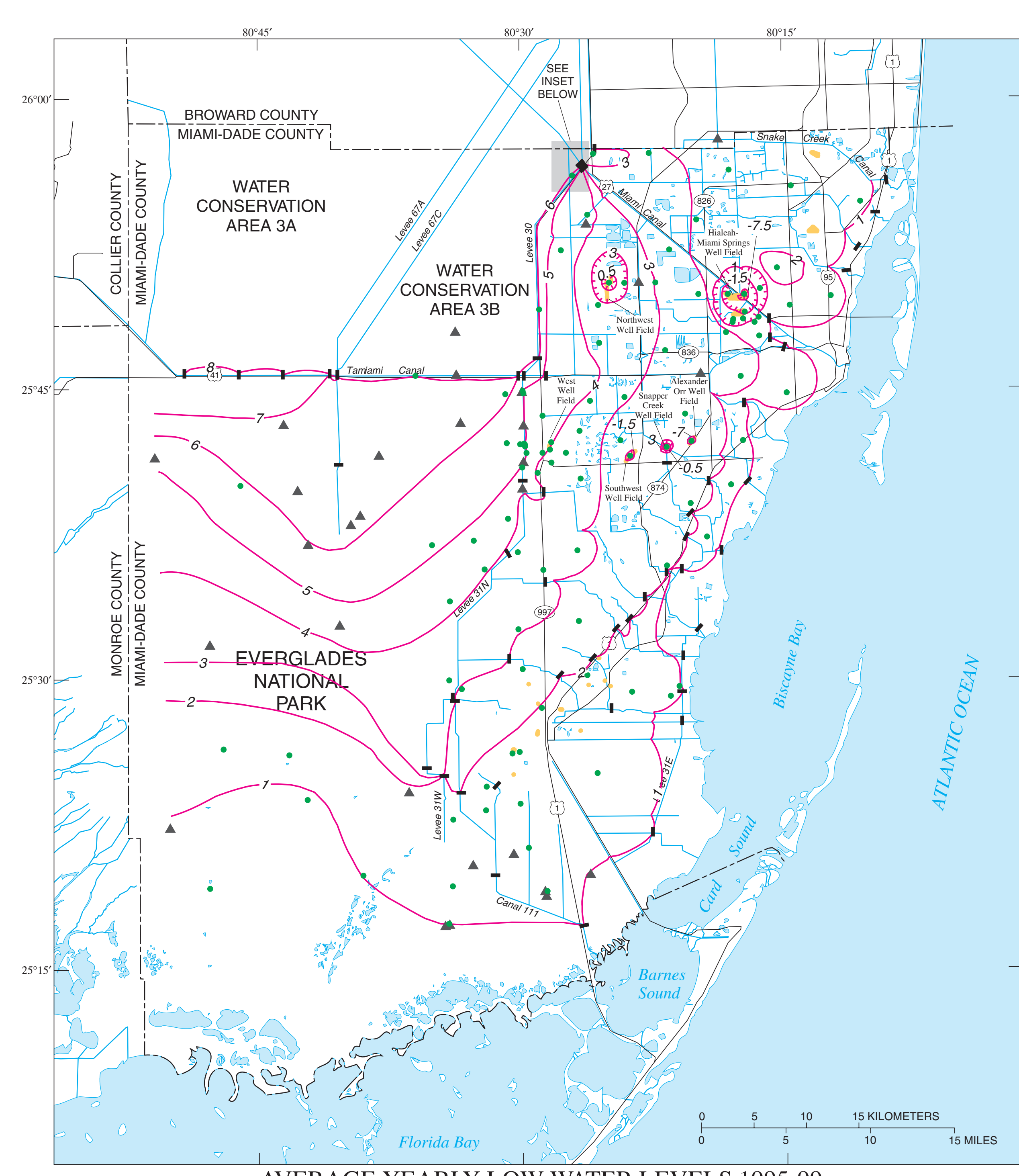

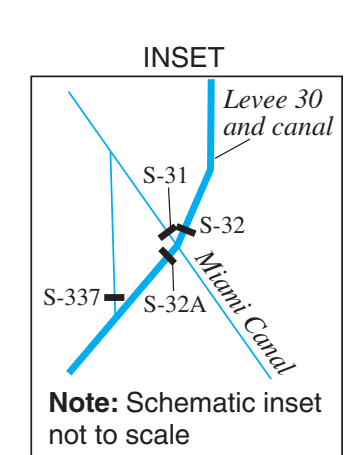

PLATE 4. MAPS SHOWING ALTITUDE OF THE WATER TABLE IN THE BISCAYNE AQUIFER, MIAMI-DADE COUNTY, FLORIDA, BASED ON AVERAGE YEARLY LOW WATER LEVELS FOR 1990-99, 1990-94, AND 1995-99

$$
\begin{gathered}
\text { By } \\
\text { A.C. Lietz, Joann Dixon, and Michael Byrne } \\
2002
\end{gathered}
$$




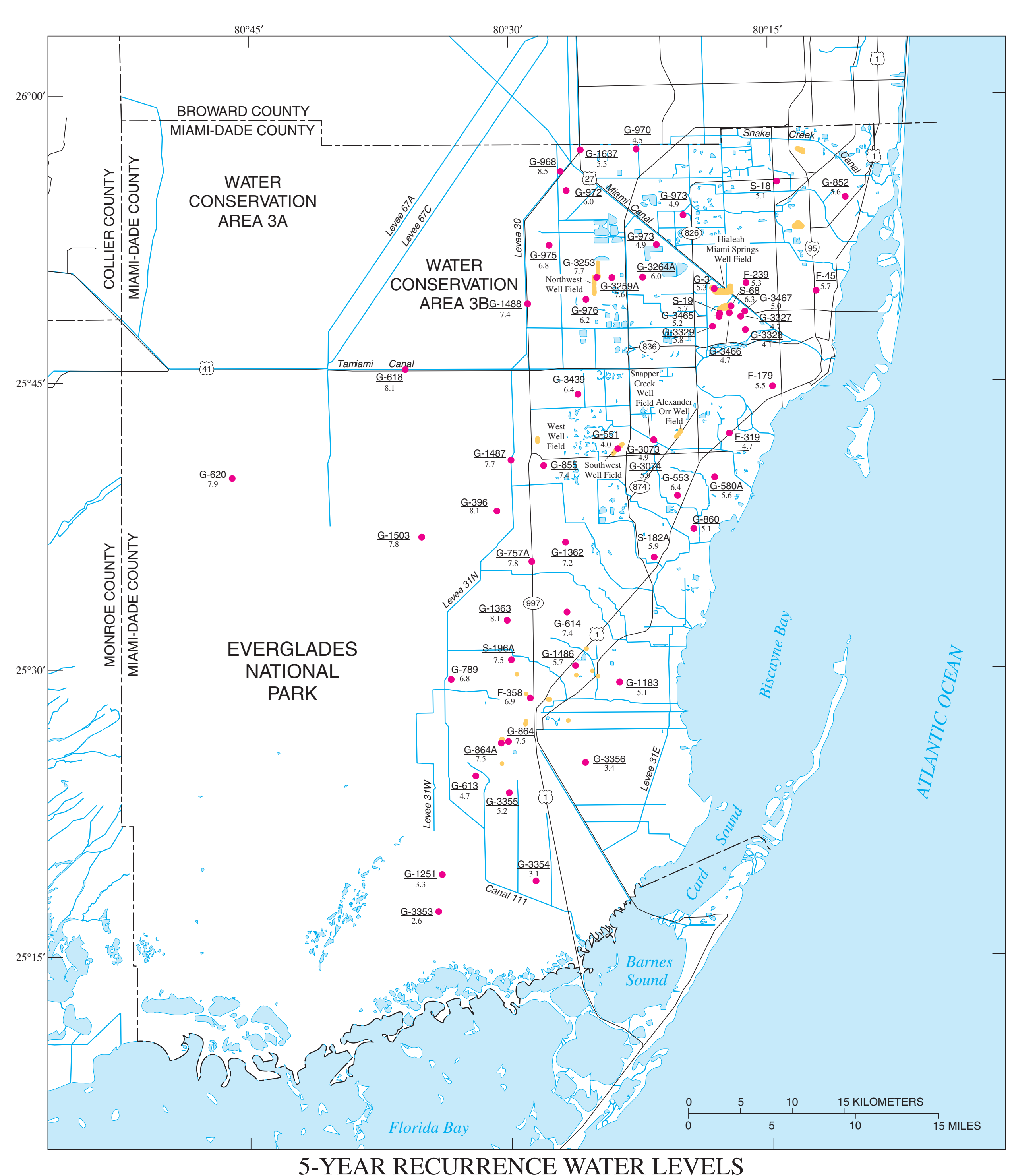

5-YEAR RECURRENCE WATER LEVELS

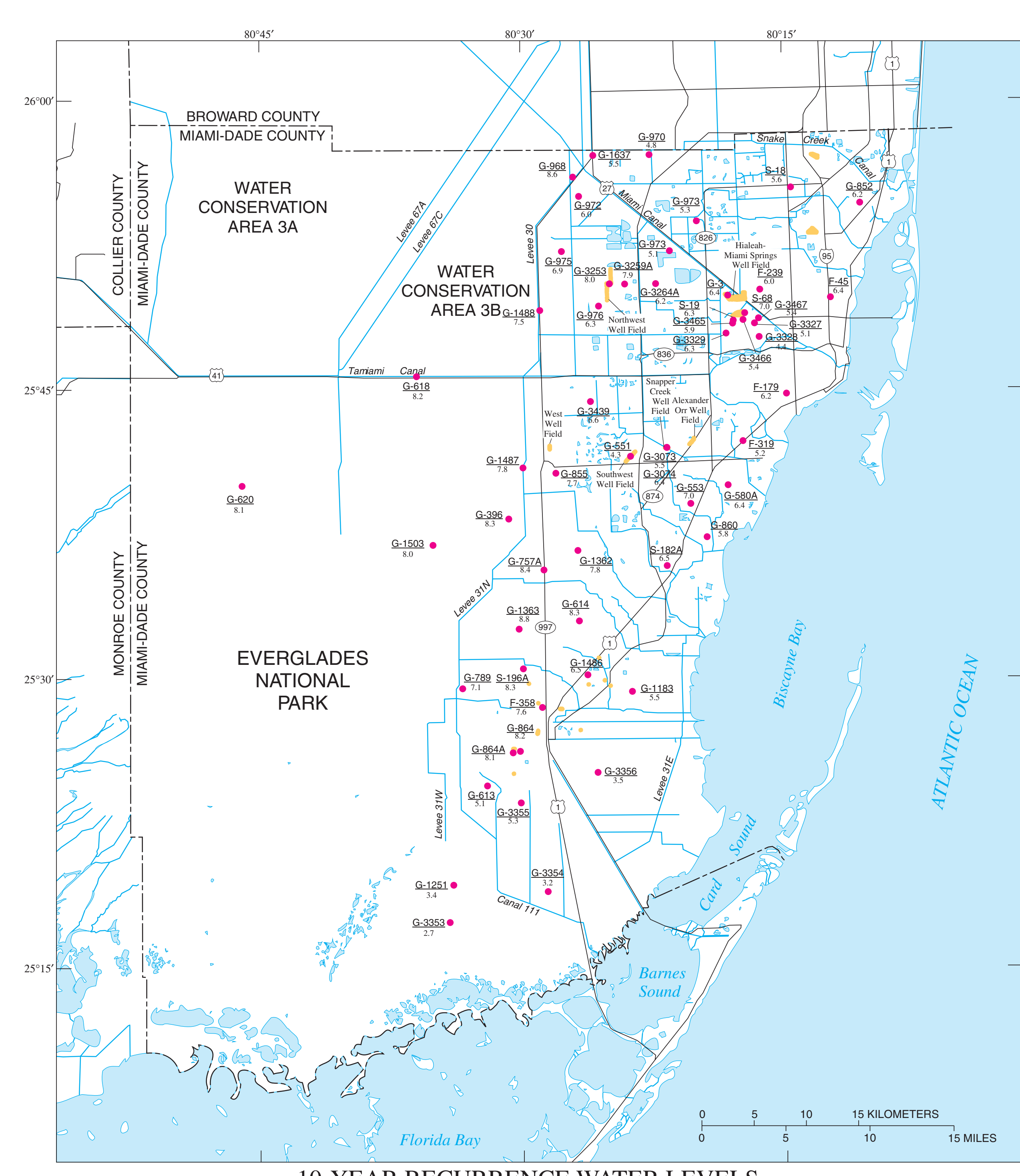

10-YEAR RECURRENCE WATER LEVELS

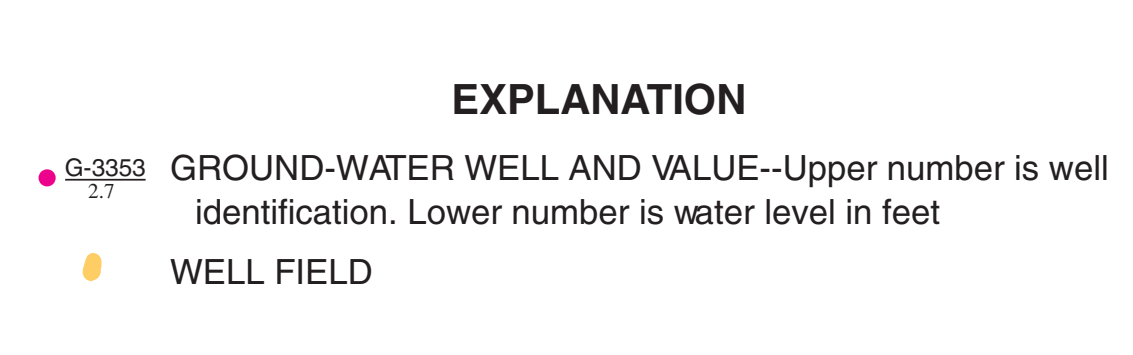

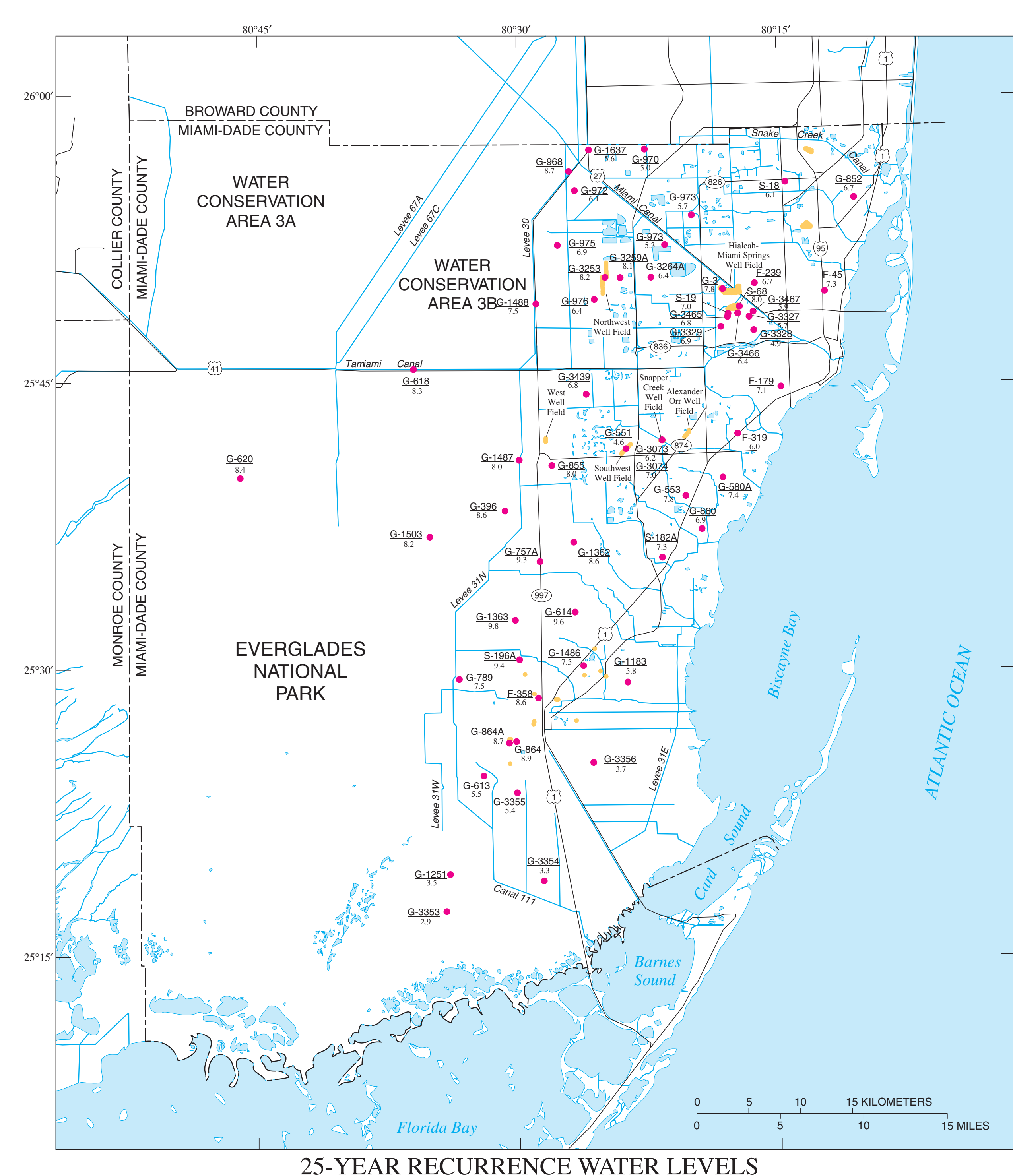

25-YEAR RECURRENCE WATER LEVELS

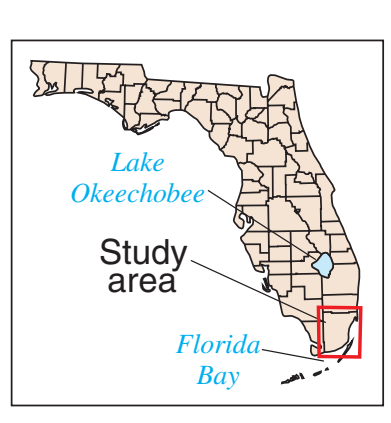

PLATE 5. MAPS SHOWING RECURRENCE WATER LEVELS OF 5, 10, AND 25 YEARS IN MIAMI-DADE COUNTY, FLORIDA, 1974-99

A.C. Lietz, Joann Dixon, and Michael Byrne 